\title{
ロッキング方式 PCa カーテン ACCOMMODATION TO OUT OF PLANE ウォールの構面外方向挙動 STORY-DRIFT OF ROCKING TYPE PRECAST CONCRETE CURTAIN WALL
}

\section{高 宏周— $* 1$ 吹田啓一郎— $* 2$ \\ 狗飼正敏——3 佐々木哲也— $* 3$ \\ キーワード : \\ プレキャストコンクリートカーテンウォール, ロッキング方式,}

構面外方向挙動, 変位追従性能

Keywords:

Precast concrete curtain wall, Rocking type, Out of plane behavior, Accomodation to story drift

\section{Kwengjoo KOH Masatoshi INUKAI $* 1$}

This paper presents results of full-scale loading tests of rocking type precast concrete curtain walls subjected to large out of plane story drift. From test results, the method to estimate the uplift behavior of the bearing support of a panel are proposed. This method extends the numerical analysis on collapse behavior of tall steel buildings. From the analysis, the rocking type precast concrete curtain walls must not reach the limit of accommodation to out of plane story drift before collapse of buildings.

1. はじめに

上町断層帯地震は長周期成分が卓越したパルス性の強い地震動を 発生し, 高層建物に現行の設計クライテリアを超える大きな応答が 生じると予測されている，例えば蘇ら ${ }^{1)}$, 佐藤ら ${ }^{2)}$ は, 川辺 ${ }^{3)}$ の予 測地震動を用いた地震応答解析により 20 層, 40 層の高層建物の最 大層間変形角が $0.03 \mathrm{rad}$ を超える結果を示している. 日本建築構造 技術者協会関西支部が主催する「大阪府域内陸直下型地震に対する 建築設計用地震動および設計法に関する研究会」により ${ }^{4)}, 13 \sim 39$ 層の 6 棟の鉄骨造高層建物を対象とする地震応答解析の例では最大 レベルの設計用地震動（速度応答スペクトルの最大值 $1.8 \mathrm{~m} / \mathrm{s}$ 程度） による最大層間変形角が $0.015 \sim 0.04 \mathrm{rad}$ となり ${ }^{5)}$, 建物倒壊限界 も含めて安全性を検討することが提案されている ${ }^{6}$.

倒壊が懸念されるほどの大変形に対する安全性を検討するとき, 外装材の落下も重要な課題である. 本論文では鉄骨造高層建物に普 及しているプレキャストコンクリートカーテンウォール（以下，PCa 帳壁と称す）を対象にこの問題 7) 8) を検討する. 現在の PCa 帳壁の 地震時の要求性能について, 建築工事標準仕様書 - 同解説 JASS $14^{9)}$ の解説によると大地震時に脱落・損傷しないことを目標とし，パネ ルの大きなひび割れ，ファスナー金物の変形，ファスナー部コンク リートの損傷等の破壊に関して構面方向層間変形角 $1 / 120 \sim 1 / 75$ 程 度が目安になると記されている。また，プレコンシステム協会によ る $\mathrm{PCa}$ 帳壁に関する基準 ${ }^{10)}$ と，カーテンウォール・防火開口部協 会による帳壁一般に関する基準 ${ }^{11)}$ の 2 種類の基準があり，いずれも パネルの脱落が生じない限界を構面方向, 構面外方向ともに層間変 形角 $1 / 100$ に設定している. これは超高層建物の 2 次設計のクライ テリアに合わせて定められており，これを超える層間変位追従性能 は一般的に求められていない.

$\mathrm{PCa}$ 帳壁の構面方向層間変位追従性能を検証した既往の実大実験 は文献 12）がある。これは鉄骨造建物の倒壊挙動を模擬して構面方 向層間変形角 $1 / 5$ に至る大変形領域での $\mathrm{PCa}$ 帳壁の挙動を検証した
もので, 変位追従限界を超えた領域での破壊挙動, 層間変形角と損 傷の関係により破壊発生時の変位予測法を示している。しかし，構 面外方向の層間変位追従性能に関する既往の研究はわずかであり ${ }^{13)}$, 対象となるファスナーの構成も現在の一般的なものと異なる.

本論文では変位追従方式として使用例の多いロッキング方式を対 象とし，PCa 帳壁の面外方向に骨組が変形したときの PCa 帳壁の挙 動を実験的に検証する．また，構面外方向層間変位が生じたときの $\mathrm{PCa}$ 帳壁のパネル取付部の挙動の予測方法について検討する.

\section{PCa 帳壁の構面外方向挙動}

$\mathrm{PCa}$ パネルは図 1 に示寸ような「振れ止め」と「荷重受け」の 2 種類のファスナーにより 4 点で鉄骨造の躯体に取付けられる．本論 文では上部 2 点を面外変形を拘束する振れ止めにより，下部 2 点を ピン支点の役割をもつ荷重受けにより取付けるタイプのロッキング 方式 $\mathrm{PCa}$ 帳壁を対象とする．また，本論文で検討するファスナーに 用いる金物は板厚 $150 \mathrm{~mm}$ の $\mathrm{PCa}$ パネルに対する標準的な寸法とし, これは文献 12）と同寸法である.

\section{1 PCa 帳壁の構面外方向挙動に影響を及ぼす建物の変形}

図 2 に鋼構造ラーメンに生じる層間変位を示寸。地震時に生じる 層間変位 $\Delta$ は柱の曲げ変形による層間変位 $\Delta_{c}$, 梁の曲げ変形による 層間变位 $\Delta_{b}$, 接合部パネルのせん断変形による層間変位 $\Delta_{p}$ の総和で ある.この中で $\mathrm{PCa}$ 帳壁の構面外方向挙動に大きく影響する層間変 位は柱の曲げ変形による層間変位 $\Delta_{c}$ であると考えられる.

現在の耐震設計による建物では，中地震時にす心゙ての構造部材は 弾性域に収まるように設計される。また，大地震時には構造部材の 塑性化が許容されるが倒壊防止の観点から崩壊系が形成される過程 で梁や接合部パネルの塑性化が先行し，その後，柱が塑性化するよ うに設計されている，従って、建物によって差異があるが，層間変 位が小さいときは柱は弾性域に留まるため, 柱の曲げ変形による層 間変位は小さく，建物に生じる層間変位が大きくなり大変形領域に

\footnotetext{
京都大学大学院工学研究科建築学専攻 修士課程

（干 615-8540 京都市西京区京都大学桂 C2 棟）

京都大学大学院工学研究科建築学専攻 教授・博士 (工学)

プレコンシステム協会
}

\footnotetext{
Graduate Student, Dept. of Architecture and Architectural Engineering, Kyoto Univ.

2 Prof., Dept. of Architecture and Architectural Engineering, Kyoto Univ., Dr. Eng. Precast Concrete System Association
} 
至ると柱は塑性化するため, 柱の曲げ変形による層間変位が大きく なると推察される. 従って, $\mathrm{PCa}$ 帳壁の構面外方向挙動は建物の変 形が大変形領域に至ったときに生じると考えられる.

本章で対象とする層間変位は, $\mathrm{PCa}$ 帳壁の構面外方向挙動に影響 を及ぼす柱の曲げ変形による層間変位 $\Delta_{c}$ とする．ここで，構面外変 位の向きは上階梁が室外側へ変位する向きを「外向き」, 室内側へ変 位する向きを「内向き」と呼ぶ.

\section{2 ファスナー部の挙動}

パネルの面外方向に骨組が変形するとき, ロッキング形式 PCa 帳 壁はファスナーが変形することにより構面外方向層間変位に追従す ると推察できる. 振れ止めについて, 文献 14）に基づきファスナー 各部の耐力を比較すると, 取付アングルの面外曲げ降伏が最初に生 じることがわかるので，この変形により層間変位に追従すると考え られ, その場合は直ちにパネルが脱落に至ることは考えにくい. また, 荷重受けは台座ピンから浮き上がることにより層間変位に追従する と考えられるので, ここでは荷重受けが台座ピンから抜け出すとき を構面外方向の変位追従限界とする.

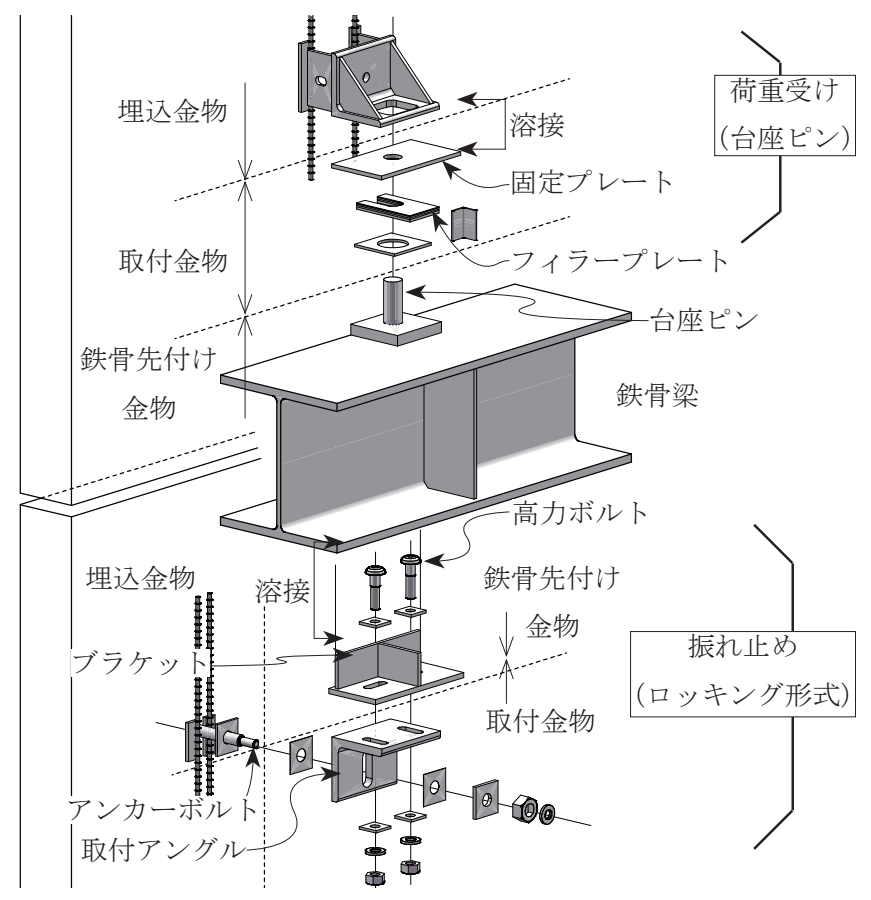

図 1 ロッキング形式のファスナーの例
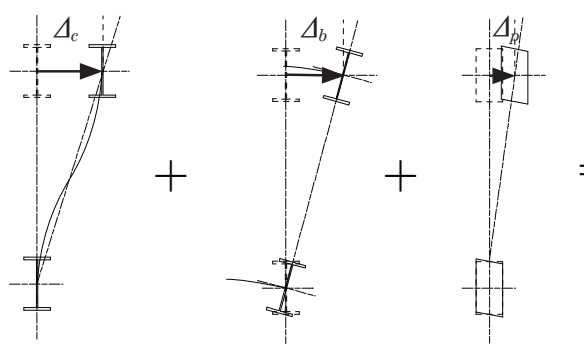

$\Delta_{c}:$ 柱の曲げ変形による層間変位

$\Delta_{b}:$ 梁の曲げ変形による層間変位

$\Delta_{p}:$ 接合部パネルのせん断変形による層間変位

$\Delta:$ 構面外方向の層間変位

$\Delta=\Delta_{c}+\Delta_{b}+\Delta_{p}$

図 2 層間変位の構成

\section{3 構面外方向外向きの変位追従限界}

図 3 に外向きの変位追従限界時の状態を示す. 図 3(a) に示す上部 梁の変位 $x_{b}, y_{b}$ は既知とする. ここで $x_{b}$ が前述の柱の曲げ変形によ る層間変位 $\Delta_{c}$ に対応する. 変形後の状態を考えると図 $3(\mathrm{c})$ に示寸荷 重受けの B 点が D 点に達したときが構面外方向外向きの変位追従限 界となる. 以下では, 上部梁の変位が与えられたときの荷重受けの 浮き上がり量 $\mathrm{c}_{v}$ を算定する式を導く.

図3(b)より,パネル回転角 $\theta_{p}$ と取付アングルの回転角 $\theta_{a}$ は等しい.

$$
\theta_{p}=\theta_{a}
$$

また, 取付アングルの面外曲げ変形によるアンカーボルト接合部の 変位 $x_{a}, y_{a}$ はパネル回転角 $\theta_{p}$ を用いて次式で表せれる.

$$
\begin{aligned}
& x_{a}=l_{x}\left(\cos \theta_{p}-1\right)-l_{y} \sin \theta_{p} \\
& y_{a}=-l_{x} \sin \theta_{p}-l_{y}\left(\cos \theta_{p}-1\right)
\end{aligned}
$$

よって, アンカーボルト接合部 $\left(\mathrm{A}\right.$ 点) の水平変位 $\Delta_{\mathrm{A}}$ は次式となる.

$$
\Delta_{\mathrm{A}}=x_{a}+x_{b}
$$

図 3(c) より, 荷重受けは $\mathrm{E}$ 点で台座ピンの台座部と接しながら浮き 上がるので，その浮き上がり量 $c_{v}$ は次式となる.

$$
c_{v}=-l_{\mathrm{BE}} \tan \theta_{p}
$$

パネルの回転による $\mathrm{C}$ 点の変位 $x_{c}, y_{c}$ は次式となる.

$$
\begin{aligned}
& x_{c}=\left(l_{\mathrm{BC}}-l_{\mathrm{BE}} \sec \theta_{p}\right) \cos \theta_{p}-l_{\mathrm{EC}} \\
& y_{c}=\left(l_{\mathrm{BC}}-l_{\mathrm{BE}} \sec \theta_{p}\right) \sin \theta_{p}
\end{aligned}
$$

図 $3(\mathrm{a})$ より, 変形後のファスナー間 $\left(\mathrm{A}^{\prime} \mathrm{C}^{\prime}\right.$ 間 $)$ の鉛直距離 $h_{v}$ は次式 となる.

$$
h_{v}=h+y_{a}+y_{b}-y_{c}
$$

また, 幾何学的関係より次式の関係が成り立つ.

$$
\theta_{p}=\tan ^{-1} \frac{\Delta_{\mathrm{A}}-x_{c}}{h_{v}}
$$

従って, (4), (7) 式より $c_{v}$ は次式となる.

$$
c_{v}=-l_{\mathrm{BE}} \frac{\Delta_{\mathrm{A}}-x_{c}}{h_{v}}
$$

\section{4 構面外方向内向きの变位追従限界}

図 4 に内向きの変位追従限界時の状態を示す. 図 4(a) に示す上階 梁の変位 $x_{b}, y_{b}$ は既知とする. ここでも $x_{b}$ は前述の $\Delta_{c}$ に対応する. 変形後の状態を考えると図 4(c) に示寸固定プレートのB 点が D 点に 達したときが構面外方向内向きの変位追従限界となる.

図 4(b) より, パネル回転角 $\theta_{p}$ と取付アングルの回転角 $\theta_{a}$ は等しい.

$$
\theta_{p}=\theta_{a}
$$

また, 取付アングルの面外曲げ変形によるアンカーボルト接合部の 変位 $x_{a}, y_{a}$ はパネル回転角 $\theta_{p}$ を用いて次式で表せれる.

$$
\begin{aligned}
& x_{a}=-l_{y} \sin \theta_{p} \\
& y_{a}=-l_{y}\left(\cos \theta_{p}-1\right)
\end{aligned}
$$

よって, アンカーボルト接合部 $\left(\mathrm{A}\right.$ 点）の水平変位 $\Delta_{\mathrm{A}}$ は次式となる.

$$
\Delta_{\mathrm{A}}=x_{a}+x_{b}
$$

図 4(c) より, 荷重受けは $\mathrm{E}$ 点で台座ピンの台座部と接しながら浮き 上がるので，その浮き上がり量 $c_{v}$ は次式となる. 


$$
c_{v}=-l_{\mathrm{BE}} \tan \theta_{p}
$$

パネルの回転による $\mathrm{C}$ 点の変位 $x_{c}, y_{c}$ は次式となる.

$$
\begin{aligned}
& x_{c}=l_{\mathrm{BC}}\left(\cos \theta_{p}-1\right) \\
& y_{c}=-l_{\mathrm{BE}} \tan \theta_{p}-l_{\mathrm{BC}} \sin \theta_{p}
\end{aligned}
$$

図 4(a)より, 変形後のファスナー間 $\left(\mathrm{A}^{\prime} \mathrm{C}^{\prime}\right.$ 間) の鉛直距離 $h_{v}$ は次式 となる。

$$
h_{v}=h+y_{a}+y_{b}-y_{c}
$$

また，幾何学的関係より次式の関係が成り立つ.

$$
\theta_{p}=\tan ^{-1} \frac{\Delta_{\mathrm{A}}-x_{c}}{h_{v}}
$$

従って，(12)，(15) 式より $c_{v}$ は次式となる.

$$
c_{v}=-l_{\mathrm{BE}} \frac{\Delta_{\mathrm{A}}-x_{c}}{h_{v}}
$$

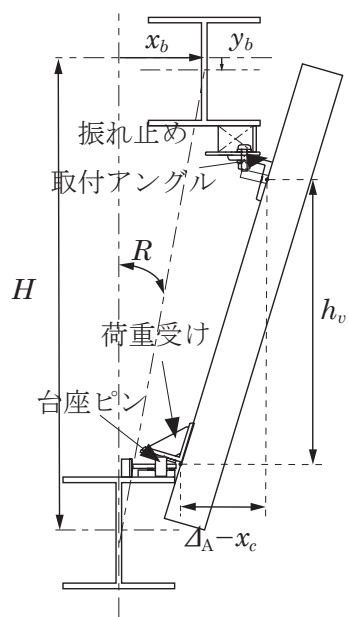

(a) パネル全体

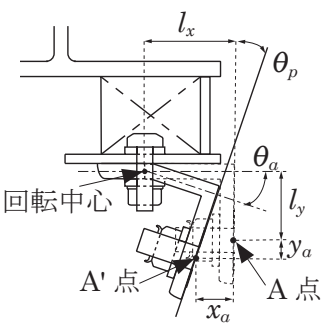

(b) 振れ止め

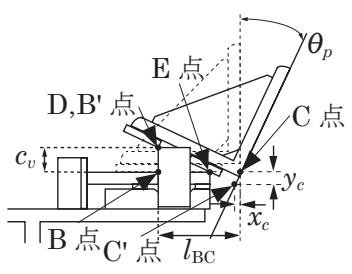

(c) 荷重受け
$H$ : 階高 $R$ : 層間変形角

$h:$ 初期のファスナー間鉛直距離（AC 間鉛直距離）

$l_{\mathrm{BC}}: \mathrm{BC}$ 間水平距離 $l_{\mathrm{BE}}: \mathrm{BE}$ 間水平距離 $l_{\mathrm{EC}}: \mathrm{EC}$ 間水平距離

図 3 構面外外向きの変位追従限界

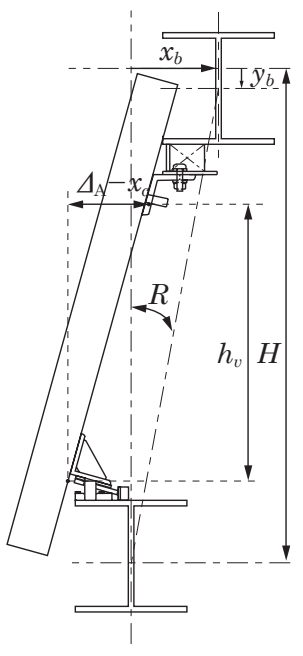

(a) パネル全体

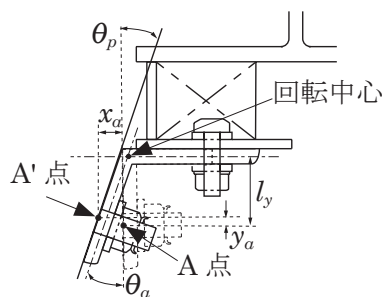

(b) 振れ止め

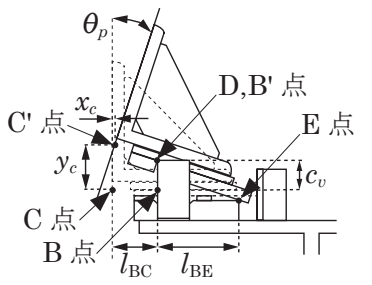

(c) 荷重受け
図 4 構面外内向きの変位追従限界

\section{3. $\mathrm{PCa}$ 帳壁の構面外方向載荷実験}

\section{1 試験体}

ロッキング形式で取付けられた $\mathrm{PCa}$ 帳壁の構面外方向層間変位に 対する変位追従性能を検証するため, 図 5 の試験体を用いて実験を 行った，実験では柱を梁にピン接合することで，柱の曲げ変形によ る層間変位を再現した。左右の上部梁を緊結することにより上部梁 の回転を抑制した。

図 6 にファスナー詳細, 図 7 にパネル詳細を示す. $\mathrm{PCa}$ パネルは 幅 $2170 \mathrm{~mm} \times$ 高さ $1730 \mathrm{~mm} \times$ 厚さ $150 \mathrm{~mm}$ の軽量 1 種コンクリー 卜製（外向き載荷時の材齢 28 日，圧縮強度は $48.4 \mathrm{~N} / \mathrm{mm}^{2}$. 内向き 載荷時の材齢 33 日, 圧縮強度は $48.6 \mathrm{~N} / \mathrm{mm}^{2}$ ) で D10（SD295A） のダブル配筋により補強されている.ファスナーは厚さ $150 \mathrm{~mm} の$ パネルに対する標準的な寸法であり，ファスナーに用いた金物の鋼 種はいずれも $400 \mathrm{~N} / \mathrm{mm}^{2}$ 級である.

\section{2 実験方法}

載荷方法は，2 本の油圧ジャッキを上部梁に取り付け，試験体のね じれを抑制し, 変位制御で層間変形角 $R=0.34 \mathrm{rad}$ まで単調載荷を行っ た.

載荷中の計測は, 載荷荷重, 上部梁の水平変位, 構面内方向のパ ネル回転角, パネルの水平・鉛直変位, 振れ止めの水平・鉛直変位, 荷重受けの水平・鉛直変位について行った。以下では層間変形角 $R$ は上部梁の水平変位とピン治具閒鈶直距離から算出した值を示す. 構面外方向のパネル回転角 $\theta_{p}$ はパネルの水平変位と計測位置の鉛直 距離から算出した. 荷重受けの浮き上がり量 $c_{v}$ と水平変位は荷重受 けの水平・鉛直変位から荷重受けの回転による影響を除いた值を算 出した.

\section{4. 実験結果}

\section{1 水平力 - 層間変形角関係}

図 8 に外向きの水平力 $Q-$ 層間変形角 $R$ 関係を示す. 水平力 $Q$ は載荷荷重と自重の影響を水平力に換算した值である。実験では $R=0.05 \mathrm{rad}$ のとき取付アングルの降伏を確認した。図 9 に荷重受け の水平変位を示す. $R=0.05 \mathrm{rad}$ で水平変位の増加が止まることから 台座ピンと固定プレートが接触したことがわかる. $R=0.12 \mathrm{rad}$ で水 平変位が再び増加することから，このときに台座ピンの曲げ変形が 始まったと考えられる。また， $R=0.20 \mathrm{rad}$ から固定プレートが面外 変形（写真 1 ）を生じたことを確認した。 $R=0.25 \mathrm{rad}$ で台座ピンの 台座部とパネルの接触（写真 2) を確認し, その後, アンカーボルト 接合部で滑りを確認した. 図 8 に示す $Q-R$ 関係は, $R=0.05,0.12,0.20$, $0.25 \mathrm{rad}$ で勾配の変化が見られ, その原因としては, 上述の事象が考 えられる.また, $R=0.12 \mathrm{rad}$ から水平力 $Q$ が増加した原因としては, 台座ピンと固定プレートが接触したことで鉛直方向にも抵抗し始め, パネルが面内方向力によりブレースのように水平力に抵抗したから と考えられる.

図 10 に内向きの $Q-R$ 関係を示す。実験では、 $R=0.05 \mathrm{rad}$ で 取付アングルの降伏， $R=0.08 \mathrm{rad}$ でアンカーボルトの曲げ降伏, $R=0.15 \mathrm{rad}$ で固定プレートの面外変形を確認した. 図 10 に示す $Q-R$ 関係は， $R=0.05 ， 0.08 ， 0.15 \mathrm{rad}$ で勾配の変化が見られ，その 原因としては，これらの事象が考えられる.また, 外向きと同じ理 由により $R=0.20 \mathrm{rad}$ から水平力 $Q$ が増加したと考えられる. 


\section{2 荷重受けの浮き上がり量 $\mathrm{C}_{\mathrm{v}}$}

図 11 に外向きの層間変形角 $R$ - 浮き上がり量 $c_{v}$ 関係, 図 12 に 層間変形角 $R$ - パネル回転角 $\theta_{p}$ 関係を示す. 図中の実線は実験 值，破線は計算值を示す。 $c_{v}, \theta_{p}$ の計算值は (7), (8) 式を用いて算 出した. 実験值 $c_{v}$ は写真 1 に示寸固定プレート側面の計測位置で 得た鈆直変位であるため, 固定プレートの面外変形を含んだ值とな る. 図 11 より, 計算值 $c_{v}$ は $R=0.20 \mathrm{rad}$ まで実験值を精度よく算 定できていることがわかる， $R=0.20 \mathrm{rad}$ から実験值と誤差が生じ る原因としては, 計算值は固定プレートの面外変形を考慮していな

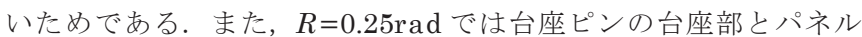
の接触により, パネル回転角 $\theta_{p}$ の増分が減少したことが確認され ており, そのために実験值 $c_{v}$ の増分が $R=0.25 \mathrm{rad}$ から減少したと 限界について考察しているため, 求めたい荷重受け浮き上がり量 は固定プレートの面外変形量を除いた值である. 載荷終了時の固 定プレートの面外変形量は約 $7 \mathrm{~mm}$ であり, $R=0.20 \mathrm{rad}$ 以降も荷 重受けの浮き上がり量 $c_{v}$ を精度よく算定できていると考えられる.

図 13 に内向きの $R-c_{v}$ 関係, 図 14 に $R-\theta_{p}$ 関係を示寸. 図中の $10 \mathrm{~mm}$ である. 実験では, 図 4(c) に示す $\mathrm{E}$ 点に接する固定プレート が局所的に面外変形していることを確認した，そのため，(16）式で 用いる $l_{\mathrm{BE}}$ の值が想定しているより小さい值となり，計算値 $c_{v}$ が実 験值よりも大きい值をとると考えられる. 推察できる。しかし，本報では荷重受けが台座ピンから抜け出す 実線は実験值，破線は計算值を示す。 $c_{v}, \theta_{p}$ の計算值は (15), (16) 式を用いて算出した。載荷終了時の固定プレートの面外変形量は約

\section{10 層骨組の倒壊挙動における PCa 帳壁の構面外方向挙動}

本章は鋼部材の局部座屈などによる耐力の低下を考慮した 10 層骨 組の倒壊挙動を非線形プログラム $\mathrm{CLAP}^{15)}$ を用いて数值解析により 得る。その結果から，10 層骨組の倒壊挙動における PCa 帳壁の荷重 受け浮き上がり量について考察する。

\section{1 解析対象}

図 15 に解析対象である 10 層骨組の平面図と立面図を示す，床重 量は $8 \mathrm{kN} / \mathrm{m}^{2}$ とし, 柱の柱頭に床重量を分配し, $A_{i}$ 分布を用いて外 力を決定した. 柱材には箱形断面 (SN490), 梁材には H 形鋼 (SN490) を使用し, 接合部パネルを考慮するとともに, 剛床仮定を用いた。 部材の劣化を伴い倒壊に至る骨組を再現するために, 柱梁部材の端 部に端部バネを設置し，梁材を剛棒，梁材の端部に位置する端部バ ネを弾塑性バネ，柱材を弾性棒，柱部材の端部に位置する端部バネ を剛塑性バネとした．端部バネの復元力特性に関しては加藤・秋山 ら ${ }^{16)}$ 17) が提案した実験式を用いて図 16 に示すようなトリニリア型 の復元力特性とした.

上述の条件を満たす部材寸法を決定した．表 1 に柱梁部材と接合 部パネル寸法, 表 2 に柱梁接合部パネルの材料特性，表 3 に柱梁耐 力比を示す. 柱梁耐力比が全層にわたってやや大きめの值をとる理 由としては, 考察対象が $\mathrm{PCa}$ 帳壁の構面外方向挙動であり, 劣化が 多層に亘って生じ，倒壊に至る骨組を意図したためである。

図 17 に層せん断力関係 - 層間変形角を示す. 図中の○プロット は最大層間変形角 $R=0.02 \mathrm{rad}$ であり, (保有水平耐力 / 必要保有水 平耐力） は全ての層で $1.16 \sim 1.17$ の值であった. さらに変形が増 加すると, 梁材の端部バネが劣化し始めることで塑性ヒンジが下層

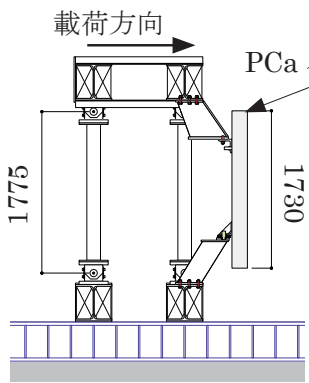

(a) 外向き

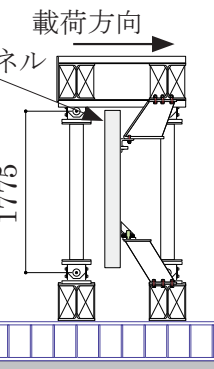

(b) 内向き
図 5 載荷装置 (単位 : $\mathrm{mm}$ )
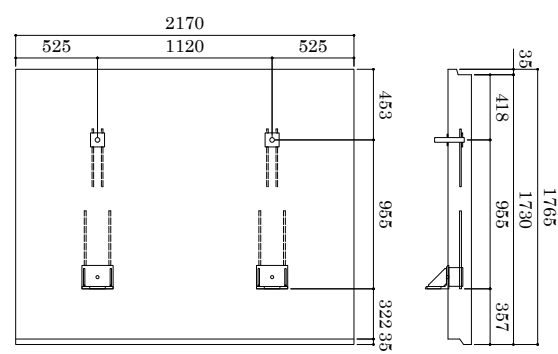

図 7 パネル詳細（単位： $\mathrm{mm}$ )

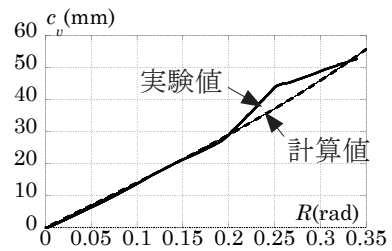

図 $11 R-c_{v}$ 関係（外向き）

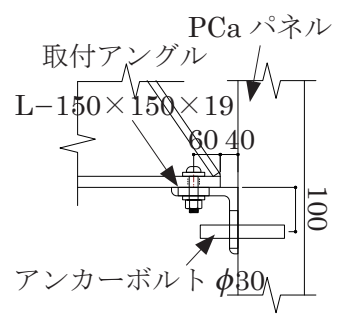

(a) 振れ止め

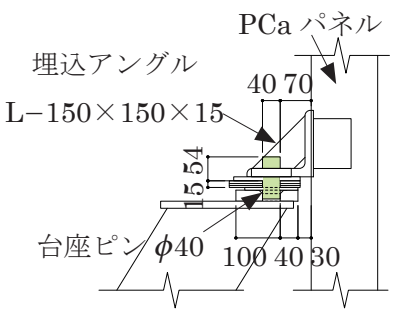

(b) 荷重受け

図 6 ファスナー部詳細（単位：mm）

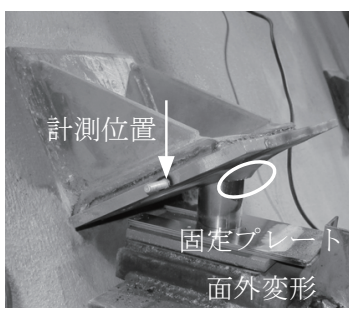

写真 1 荷重受け

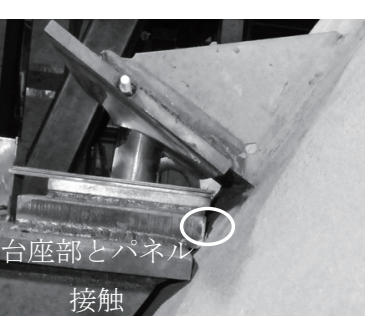

写真 2 台座ピン

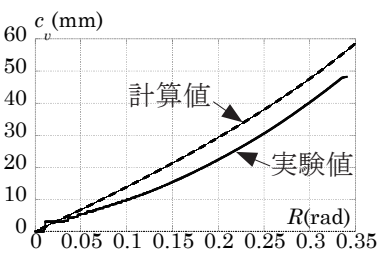

図 $13 R-c_{v}$ 関係（内向き）

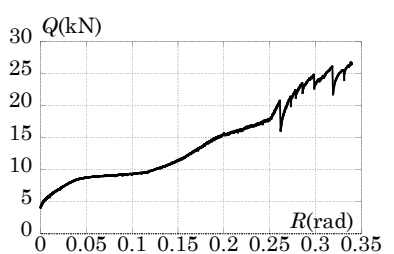

図 $8 Q-R$ 関係（外向き）

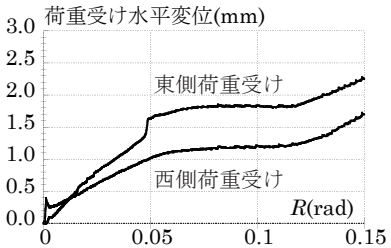

図 9 荷重受け水平変位 (外向き)

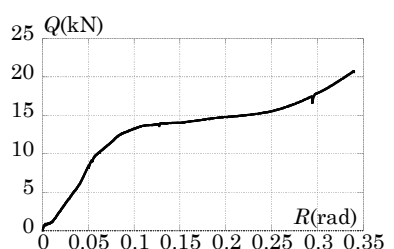

図 $10 Q-R$ 関係（内向き）

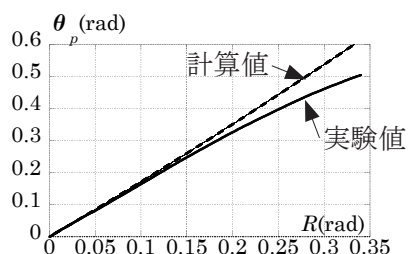

図 $14 R-\theta_{p}$ 関係（内向き） 

きる. は次式となる.

部に移行し, 図中の $\boldsymbol{\Delta}$ プロットで示寸最大層間変形角 $R=0.085 \mathrm{rad}$ 時点で図 18 に示寸ように 1 層柱脚と 4 層柱頭に塑性ヒンジが生じ, 倒壊に至った．PCa 帳壁の構面外方向挙動は柱の曲げ変形による層 間変位 $\Delta_{c}$ が大きく影響することから, 荷重受けの浮き上がり量は 4 層で最も大きくなると考えられ, 図 19 に示寸 4 層の層間変形角の 構成より層間変形角 $R=0.085 \mathrm{rad}$ 付近から $\Delta_{c}$ が増加することから, $R=0.085 \mathrm{rad}$ 以降に荷重受け浮き上がり量が大きく増加すると推察で

\section{2 骨組における荷重受けの浮き上がり量の算定法}

実際の骨組の倒壞挙動では, 柱の曲げ変形による層間変位 $\Delta_{c}$ 以外 に梁の曲げ変形による層間変位 $\Delta_{b}$ と接合部パネルのせん断変形によ る層間変位 $\Delta_{p}$ が生じるため, $(1) \sim(16)$ 式だけでは荷重受け浮き上 がり量を算定することができない，従って、本節では梁の曲げ変形 と接合部パネルのせん断変形によるパネル取付部の梁の回転を考慮 して荷重受け浮き上がり量を算定する方法を提示する.

数值解析で得られた上部梁の水平・鉛直変位 ${ }_{t} x_{b},{ }_{t} y_{b}$, 節点回転角 ${ }_{t} \theta_{n}\left(=\right.$ 梁の曲げ変形によるもの), 接合部パネルのせん断変形角 ${ }_{t} \gamma_{p}$, 下部梁の水平・鉛直変位 ${ }_{b} x_{b},{ }_{b} y_{b}$, 節点回転角 ${ }_{b} \theta_{n}$, 接合部パネルの せん断変形角 ${ }_{b} \gamma_{p}$ を用いて荷重受けの浮き上がり量を算定する．柱の 曲げ変形と接合部パネルのせん断変形によるファスナー取付部の上 部・下部梁の回転量 ${ }_{t} \theta_{f},{ }_{b} \theta_{f}$ は次式となる.

$$
\begin{aligned}
& { }_{t} \theta_{f}={ }_{t} \theta_{n}+{ }_{t} \gamma_{p} / 2 \\
& { }_{b} \theta_{f}={ }_{b} \theta_{n}+{ }_{b} \gamma_{p} / 2
\end{aligned}
$$

図 20 に上部梁の回転によるアンカーボルト接合部の変位を示す．図 より, 上部梁の回転 ${ }_{t} \theta_{f}$ によるアンカーボルト接合部の変位 ${ }_{t} x_{p},{ }_{t} y_{p}$

$$
\begin{aligned}
& { }_{t} x_{p}={ }_{t} L_{x}\left(\cos \theta_{t}-1\right)-{ }_{t} L_{y} \sin \theta_{t} \theta_{f} \\
& { }_{t} y_{p}=-{ }_{t} L_{x} \sin { }_{t} \theta_{f}-{ }_{t} L_{y}\left(\cos _{t} \theta_{f}-1\right)
\end{aligned}
$$

図 21 に下部梁の回転による荷重受け位置の変位量を示す. 図より, 下部梁の回転 ${ }_{b} \theta_{f}$ による荷重受け位置の変位 ${ }_{b} x_{p},{ }_{b} y_{p}$ は次式となる.

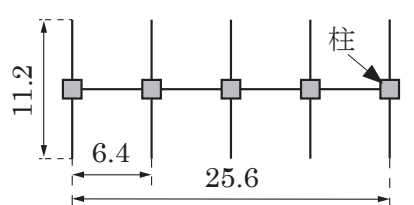

(a) 平面困

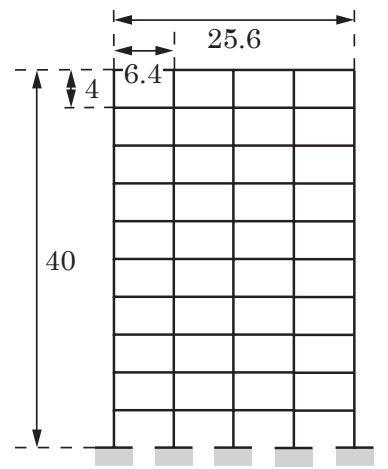

(b) 立面図

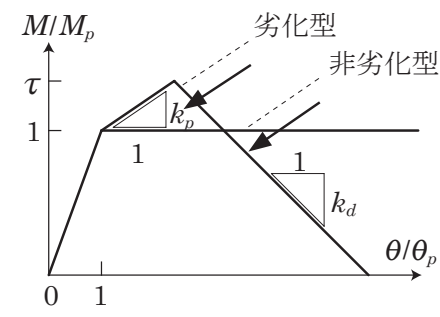

図 16 端部バネの復元力特性

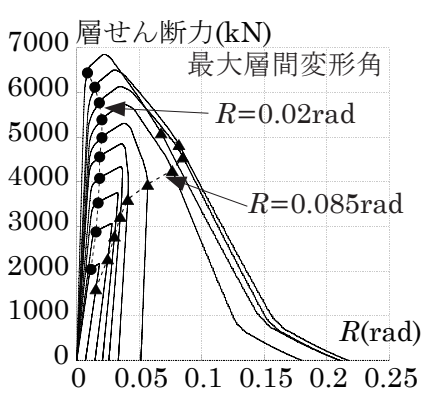

$$
\begin{aligned}
& { }_{b} x_{p}={ }_{b} L_{x}\left(\cos _{b} \theta_{f}-1\right)+{ }_{b} L_{y} \sin { }_{b} \theta_{f} \\
& { }_{b} y_{p}=-{ }_{b} L_{x} \sin { }_{b} \theta_{f}+{ }_{b} L_{y}\left(\cos { }_{b} \theta_{f}-1\right)
\end{aligned}
$$

従って，(1), (9) 式で表したパネル回転角 $\theta_{p},(3),(11)$ 式で表した アンカーボルト接合部（A 点）の水平変位 $\Delta_{\mathrm{A}}$ と (6), (14) 式で表し た変形後のファスナー間 $\left(\mathrm{A}^{\prime} \mathrm{C}^{\prime}\right.$ 間 $)$ の水平距離 $h_{v}$ は次式に置き換え られる。

$$
\begin{aligned}
& \theta_{p}={ }_{t} \theta_{f}+\theta_{a} \\
& \Delta_{\mathrm{A}}=x_{a}+\left({ }_{t} x_{b}-{ }_{b} x_{b}\right)+\left({ }_{t} x_{p}-{ }_{b} x_{p}\right) \\
& h_{v}=h+y_{a}+\left({ }_{t} y_{b}-{ }_{b} y_{b}\right)+\left({ }_{t} y_{p}-{ }_{b} y_{p}\right)-y_{c}
\end{aligned}
$$

また，幾何学的関係より次式が成り立つ.

$$
{ }_{t} \theta_{f}+\theta_{a}=\tan ^{-1} \frac{\Delta_{\mathrm{A}}-x_{c}}{h_{v}}
$$

外向きの荷重受け浮き上がり量 $c_{v}$ は以下の手順で導出する. (23) 式に (2), (5), (17) ～(19), (21), (22) 式を代入した方程式を解くこ とで取付アングルの回転角 $\theta_{a}$ が得られる.この $\theta_{a}$ を(20) 式に代入 することでパネル回転角 $\theta_{p}$ が得られ，これを(4) 式に代入すること で荷重受け浮き上がり量 $c_{v}$ が得られる.

内向きの荷重受け浮き上がり量 $c_{v}$ は以下の手順で導出する. (23) 式に (10), (13), (17) ～(19), (21), (22) 式を代入した方程式を解く ことで取付アングルの回転角 $\theta_{a}$ が得られる.この $\theta_{a}$ を $(20)$ 式に代 入することでパネル回転角 $\theta_{p}$ が得られ，これを (12) 式に代入するこ とで荷重受け浮き上がり量 $c_{v}$ が得られる.

表 1 柱梁部材と接合部パネル寸法（単位：mm）

\begin{tabular}{|c|c|c|c|}
\hline 層 & 柱 $(D \times t)$ & 梁 $\left(D \times B \times t_{w} \times t_{f}\right)$ & $\begin{array}{c}\text { 接合部パネル } \\
\left(d_{b} \times d_{c} \times t_{p}\right)\end{array}$ \\
\hline $9-10$ & $400 \times 32$ & $500 \times 250 \times 9 \times 22$ & $478 \times 368 \times 64$ \\
\hline $7-8$ & $450 \times 36$ & $600 \times 250 \times 12 \times 25$ & $575 \times 414 \times 72$ \\
\hline $4-6$ & $500 \times 36$ & $650 \times 300 \times 16 \times 25$ & $625 \times 464 \times 72$ \\
\hline $1-3$ & $550 \times 36$ & $700 \times 300 \times 12 \times 28$ & $672 \times 514 \times 72$ \\
\hline
\end{tabular}

表 2 柱梁接合部パネルの材料特性

\begin{tabular}{|c|c|c|c|c|}
\hline 部材 & $\sigma_{y}\left(\mathrm{~N} / \mathrm{mm}^{2}\right)$ & $E\left(\mathrm{~N} / \mathrm{mm}^{2}\right)$ & 2 次剛性比 & $G\left(\mathrm{~N} / \mathrm{mm}^{2}\right)$ \\
\cline { 1 - 1 } 柱 & \multirow{2}{*}{358} & $2.05 \times 10^{5}$ & 0.01 & $7.88 \times 10^{4}$ \\
\cline { 1 - 1 } 梁 & & & & \\
\cline { 1 - 1 } 接合部パネル & & & & \\
\cline { 1 - 2 }
\end{tabular}

表 3 柱梁耐力比

\begin{tabular}{|c|c|c|c|c|}
\hline 層 & $1-3$ & $4-6$ & $7-8$ & $9-10$ \\
\hline 柱梁耐力比 & 2.43 & 2.21 & 2.38 & 2.42 \\
\hline
\end{tabular}

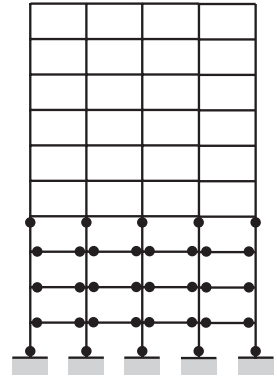

図 18 ヒンジ状況

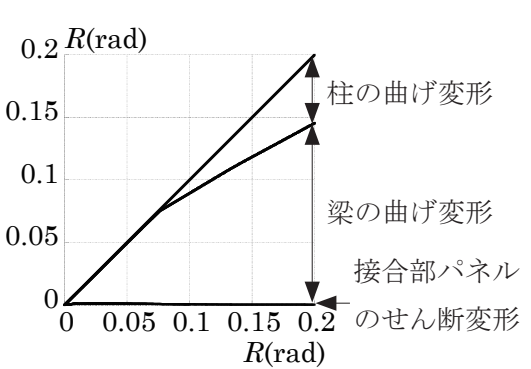

図 19 層間変形角の構成 (4 層)
図 15 解析対象 (単位：m） 図 17 層せん断力関係 - 層間変形角 


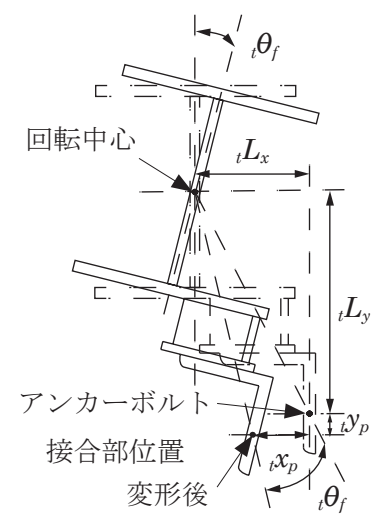

図 20 上部梁の回転による アンカーボルト接合部の変位

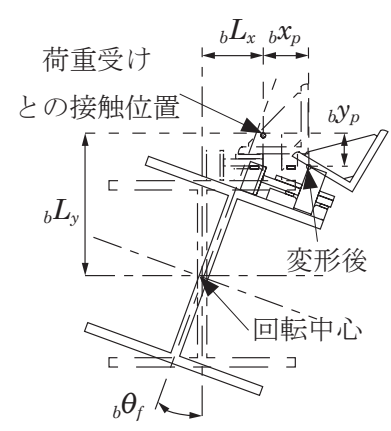

図 21 下部梁の回転による 荷重受け位置の変位

\subsection{0 層骨組の倒壊挙動における荷重受け浮き上がり量}

図 22 に 5.2 節で導出した荷重受け浮き上がり量の算定法を用い て，10 層骨組の荷重受け浮き上がり量を算出した結果を示す. 図よ り，外向きと内向きともに層間変形角 $R=0.085 \mathrm{rad}$ 付近から荷重受 け浮き上がり量は増加し，5.1節で予測したように 4 層が最も大きい 值となった。しかし, 骨組が倒壊に達するほどの大変形 $(R=0.18 \mathrm{rad})$ を受けた場合でも荷重受け浮き上がり量は $10.5 \mathrm{~mm}$ 程度であり，荷 重受けに設けられたクリアランス（54mm）に達しないことを確認 した．従って，本事例では骨組の倒壊以前に $\mathrm{PCa}$ 帳壁の構面外方向 挙動による荷重受けの抜け出し（構面外方向の変位追従限界）は生 じないと考えられる.

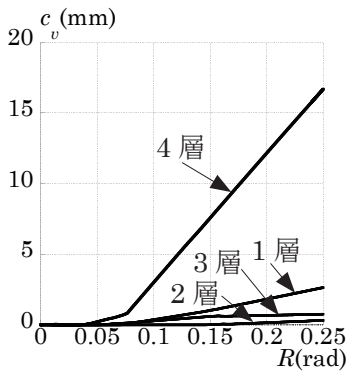

(a) 外向き

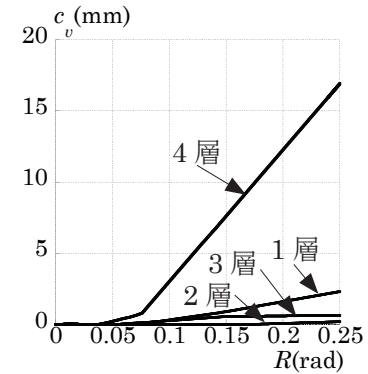

(b) 内向き

図 2210 層骨組の荷重受けの浮き上がり

\section{6. 結論}

上部を振れ止め，下部を荷重受けで取付けたロッキング形式の $\mathrm{PCa}$ 帳壁が構面外方向の層間変位を受ける場合の挙動を実験的に明 らかにし, 以下の知見を得た。

1) PCa 帳壁の構面外方向載荷実験を行い, パネルの挙動を確認した. 荷重受けの浮き上がり量 $c_{v}$, パネル回転角 $\theta_{P}$ を幾何学的関係から 算定する方法を提案し, その妥当性を実験的に確認した.

2）10 層骨組の倒壊解析の結果に提案した荷重受け浮き上がり量の算 定式を適用した事例により，骨組の倒壊までにパネルの脱落や台 座ピンの抜け出しは生じにくいことを確認した。

なお，骨組の層数などの条件が異なる場合でも，骨組に生じる $\Delta_{c}$ の大きさが本検討と同等であれば，台座ピンの抜け出しは生じにく いと推察される。また，構面外と構面方向の挙動を同時に受ける PCa 帳壁では台座ピンの抜け出しが生じうると推察できる.

謝辞

本研究は科学研究費・挑戦的萌芽研究（No.24656322）および日 本鉄鋼連盟・教育研究助成（重点テーマ研究）の助成を受けた.

\section{参考文献}

1) 蘇鐘鈺, 佐藤浩太郎, 川辺秀憲, 吹田啓一郎, 林康裕, 佐藤篤司：上町断 層帯に対する予測地震動に対する超高層建物の平面骨組モデルによる解 析，日本建築学会技術報告集，第 16 巻，第 32 号，pp.75-80，2010.2

2) 佐藤浩太郎, 蘇鐘鈺, 川辺秀憲, 吹田啓一郎, 林康裕：上町断層带の予測 地震動に対する超高層建物の建物応答, 日本建築学会技術報告集, 第 16 巻, 第 33 号, pp.493-468, 2010.6

3）川辺秀憲，釜江克宏：上町断層带の地震を想定した強震動予測，日本建築 学会近畿支部耐震構造研究部会シンポジウム資料, pp.17-24, 2009.1

4）多賀謙蔵, 亀井功, 角彰, 近藤一雄, 林康裕, 宮本裕司, 井上一郎：上 町断層帯地震に対する設計用地震動ならびに設計法に関する研究（その 1 設計用地震動ならびに設計法に関する基本方針), (その 2 設計用地震動 の概要), 日本建築学会大会学術講演梗概集, 構造 B-1, pp.127-130, 2011.8

5）福本義之, 西村勝尚, 田中嘉一, 上森博, 堀本明伸, 多賀謙蔵, 吹田啓一郎, 多田元英：上町断層帯地震に対する設計用地震動ならびに設計法に関する 研究, (その 5 既存鉄骨造建物の地震応答解析結果), 日本建築学会大会学 術講演梗概集, C-1 構造III, pp.689-690, 2011.9

6) 西村勝尚, 多賀謙蔵, 福本義之, 田中嘉一, 吹田啓一郎, 多田元英, 田中剛, 向出静司：上町断層帯地震に対する設計用地震動ならびに設計法に関する 研究，(その 6 鉄骨造建物の設計法の提案)，日本建築学会大会学術講演梗 概集， C-1 構造III，pp.691-692，2011.9

7）プレコンシステム協会 : 平成 7 年兵庫県南部地震 $\mathrm{PC}$ カーテンウォール被 害調査報告第 2 報, 1997.4

8）プレコンシステム協会・技術部会:平成 23 年東北地方太平洋沖地震 $\mathrm{PC}$ カー テンウォール地震被害調査報告, 2012.6

9） 日本建築学会：建築工事標準仕様書・同解説 JASS14 カーテンウォール 工事，2.5.2 項 層間変位追従性能，第 3 版，2012.

10）プレコンシステム協会 : プレキャストカーテンウォール計算例（暫定改 訂版， I 総則，p1，2009.6)

11）カーテンウォール・防火開口協会 : カーテンウォール性能基準 2003, pp.9-14, 2003.12

12) 吹田啓一郎, 平郡竜志, 高宏周, 聲高裕治, 狗飼正敏, 佐々木哲也：ロッ キング形式 PCa カーテンウォールの構面方向変位追従限界と限界後の挙 動, 日本建築学会構造系論文集, 第 78 巻, 第 693 号, pp.1841-1850, 2013.11

13）二階盛, 亀田泰弘, 安部一郎, 小林美亀雄, 畑野肇, 大川潤 : PC カーテ ンウォール取付け金具の実験的研究 (その 1) スライドファスナーの性能 実験, 日本建築学会大会学術講演梗概集 (東海), 構造系, pp.317 318, 1976.10

14）プレコンシステム協会・技術部会 : プレキャストコンクリート・カーテン ウォール計算例 (PART2. 取付け金物の計算), pp.29-57, 1999.6

15）小川厚治, 多田元英: 柱・梁接合部パネルの変形を考慮した静的・動的応 答解析プログラムの開発，第 17 回情報・システム・利用・技術シンポジ ウム論文集，pp.78-84，1994.12

16）加藤勉, 秋山宏, 帯洋一：局部座屈を伴う H 形断面部材の変形, 日本建築 学会論文報告集, 第 257 号, pp.49-57, 1977.7

17) 加藤勉, 秋山宏, 北沢進 : 局部座屈を伴う箱形断面部材の変形, 日本建築 学会論文報告集, 第 268 号, pp.71-76, 1978.6

[2014 年 6 月 16 日原稿受理 2014 年 10 月 30 日採用決定］ 